\title{
Benoît Vermander, Chine brune ou Chine verte? Les dilemmes de l'État-Parti
}

Paris, Les Presses de Sciences Po, 2007, 212 pp.

Jean-Paul Maréchal

\section{OpenEdition}

\section{Journals}

Electronic version

URL: http://journals.openedition.org/chinaperspectives/4757

DOI: $10.4000 /$ chinaperspectives. 4757

ISSN: 1996-4617

\section{Publisher}

Centre d'étude français sur la Chine contemporaine

Printed version

Date of publication: 1 December 2008

Number of pages: 109-111

ISSN: 2070-3449

\section{Electronic reference}

Jean-Paul Maréchal, « Benoît Vermander, Chine brune ou Chine verte? Les dilemmes de l'État-Parti », China Perspectives [Online], 2008/4 | 2008, Online since 01 December 2008, connection on 21

September 2020. URL : http://journals.openedition.org/chinaperspectives/4757 ; DOI : https://doi.org/ 10.4000/chinaperspectives.4757

This text was automatically generated on 21 September 2020.

(c) All rights reserved 


\title{
Benoît Vermander, Chine brune ou Chine verte? Les dilemmes de l'État- Parti
}

Paris, Les Presses de Sciences Po, 2007, 212 pp.

\author{
Jean-Paul Maréchal
}

1 Three decades after its brilliantly successful conversion to market economy, and seven years after its entry into the World Trade Organisation, China is now confronted with intermeshed social and environmental threats that could well short-circuit a portion of its patiently built achievements. The leadership's decisions in the next few years could as easily plunge China into a structural crisis as impart a new dynamism, says Benoît Vermander. China, he says, is caught between two paradigms: "brown China" and "green China." The first term stands for a strategy of social control, pursuit of high growth rates whatever the social and ecological cost, and immediate maximisation on the international arena of the advantages linked to the country's rise. The second term denotes political liberalisation and promotion of sustainable development as well as international cooperation.

2 Naturally, these options are poles apart, two ideal types that delimit the area of possibilities as much as they define the government's plans. Equally, there can be a whole range of possible choices in between. But these are difficult choices for the authorities, who have to find an "optimum" formula between internal tensions and external constraints, or in other words simultaneously (and ideally) pursue "harmonious society" (retermed "scientific development" since 2007) at home and "peaceful rise (or development)" internationally. On this choice depends China's future, but also that of the world, given the Middle Kingdom's central role on the global arena.

3 Internal tensions stem notably from rising inequality and ecological crisis. A 2006 report by the Chinese Academy of Social Sciences said 10 percent of the richest families in China held nearly half ( 45 percent) of private wealth, while the poorest 10 percent held a mere 2 percent. In 2005, the richest decile of the population enjoyed incomes 12 
times those of the poorest decile. In addition to these inequalities, of a magnitude comparable to those in Latin America, there are a number of problems linked to land distribution, health, education, and working conditions (4,700 deaths in mines every year). As for ecological problems, they affect all strata and all milieus (water, air, and soil). Some figures are worth noting: each year outside air pollution causes between 350,000 and 400,000 deaths, polluted water claims 60,000 lives, and by 2020 there will be some 20 million ecological refugees. China is home to five of the world's most polluted cities, 70 to 80 percent of cancer cases diagnosed in Beijing are linked to the environment, and the capital's water table has fallen by 37 metres in 40 years. And there were 161 serious ecological accidents in 2006. The list goes on.

It thus comes as no surprise to learn that in 2005 there were 87,000 protests involving more than 100 people, of which 50,000 were over pollution. Along with these internal problems are those of managing economic might on the international scene. How to ease several years of uninterrupted double-digit growth rates while keeping weaknesses at bay, and without engaging in potentially ruinous trade conflicts or strategic rivalries? The Chinese doctrine is expressed in two words: "peaceful rise" or "peaceful development" (this second formulation being deemed less aggressive). Through this expression popularised in 2003, the authorities were signalling the following action guidelines: identifying Chinese interests as being part of those of developing countries (at least in precept), holding fast to the non-interference principle, proclaiming the peaceful character of Chinese culture, and supporting multilateralism as a means of repelling antagonism to China's rise.

5 The linkages between the internal and external equations consist in what some call the "Beijing consensus," meaning the doctrine according to which "(internal) political issues can only be addressed after economic development has reached a certain level."

6 All this leads to a "conditional multilateralism," that is to say Beijing's balancing between multilateral engagement (China, for example, joined the International Atomic Energy Agency and the Nuclear Non-Proliferation Treaty, signed 30 environment conventions, has preferred to abstain rather than cast a veto in the UN Security Council...) and instrumentalisation of the principles of peaceful coexistence (mutual respect, non-aggression). As Vermander analyses, the Chinese conception of multilateralism is "founded on building ad hoc consensus regulated and tempered by national sovereignty prerogatives." In other words, "China feels more at ease in a long term 'constructivism' than in a multilateral management of international crises."

7 Suffice it to say that the Communist Party is confronted with growing domestic unrest linked to environmental and social problems, but also to the fact that the more an economy develops, the more diverse and complex the stakes and demands - so much so that while the Communist Party has allowed the country to score political and economic successes, thereby assuring itself of a high degree of legitimacy in people's eyes, it could well fall victim to the pursuit of modernisation of society (how to limit the powers that are being conceded) as well as to a serious economic and social crisis (which could lead to the Party's rupture). "If it transforms itself too little, the Party loses touch with society. If it transforms itself too much, it loses its essence and its clarity" (p.166). For now, the Party appears to be weakened more through corruption, which hurts its image, and through some problems of "governance" than through a strong demand from society for Western- style democratisation, which General Secretary Hu Jintao sees as a recipe for "impasse." Hence the idea put forward by Hu of 
gradually developing democracy at the level of the Party's 73 million members, which the Party School theoreticians have dubbed "consultative democracy."

So, brown China or green China? How can Europe help the Middle Kingdom choose the better alternative? The solution, Vermander says, lies in an open and pragmatic attitude to which theoreticians would have no objection: "Play the multilateral engagement game everywhere that China can make a positive contribution, and [...] derogate from these normal rules where China feels constrained, so as to ensure that China's 'conditional multilateralism' is not identical to an instrumentalisation of principles that undermine international confidence and cooperation." China needs to be more deeply engaged in discussions to gradually establish global governance rules. This provides the European Union with four paths of reflection and action: make sustainable development and cultural diversity the major axis of relations with Beijing; do everything to help China's civil society nurture the emergence of a "green China"; ensure strategic balance with the United States; and finally, avoid pitting India against China. If these points are ensured, there will be a better chance of china taking the green rather than the brown road. By becoming a major actor in the global arena, as shown again in September 2008 through the first space walk by a "taikonaut," China has managed to ensure that its domestic changes concern everyone. It is therefore gratifying that Vermander has presented, in a limpid style, his deep knowledge of the Chinese world to help grasp some of the essential stakes in the new century.

Translated by N. Jayaram 